\title{
Nature of basal debris in the GISP2 and Byrd ice cores and its relevance to bed processes
}

\author{
Anthony J. Gow and Debra A. Meese \\ U.S. Army Cold Regions Research and Engineering Laboratory, 72 Lyme Road, Hanover, NH 03755, U.S.A.
}

\begin{abstract}
Successful core-drilling to bedrock of both the Greenland and Antarctic ice sheets offers unique opportunities for examining processes acting at the bed. At Byrd Station, Antarctica, penetration of the bed was accompanied by upwelling of glacial meltwater into the drillhole. The nature and disposition of sediment in the $4.83 \mathrm{~m}$ thick debris-rich basal ice, together with stable-isotope and gas analyses of the enclosing ice, confirm that incorporation of the debris occurred simultaneously with periodic "freeze-on" of basal meltwater. Currently, the presence of substantial meltwater at the ice/rock interface likely precludes any erosive activity at the bed. At GISP2, Greenland, basal silty ice, $13.1 \mathrm{~m}$ thick, is currently frozen to the bed at $-9^{\circ} \mathrm{C}$. Limited studies of the silty ice at GISP 2, together with results of more comprehensive investigations obtained by GRIP researchers on basal ice at a companion site at Summit indicate that the sediment-bearing basal ice likely formed in the absence of an ice sheet and was therefore unrelated to direct interaction of the present ice sheet with its bed. The fact that the basal ice at Summit is frozen to the bottom also precludes any likelihood of erosive activity at the bed.
\end{abstract}

\section{INTRODUGTION}

The twin questions of the nature of sediment incorporation at the base of thick polar ice sheets and of their erosive capacities have been a matter of conjecture, largely due to lack of access to the bed. Observations of sediment incorporation at the edges of ice sheets likely reflect localized interaction of the ice with their beds, but it is hazardous, at best, to extrapolate such findings to the interiors of large ice sheets. In 1993 the Greenland ice sheet at the GISP2 Summit, central Greenland, site was successfully core-drilled to bedrock. This, in conjunction with an earlier successful drilling to bedrock of the Antarctic ice sheet at Byrd Station, now offers, first-hand, the opportunity to examine processes occurring in the immediate vicinity of the ice/bedrock interface of thick polar ice sheets.

\section{RESULTS AND DISCUSSION}

\section{Byrd Station}

The nature of stratified debris in ice cores from the bottom of the Antarctic ice sheet at Byrd Station has been reported in detail by Gow and others (1979). For purposes of the present intercomparison with sediment incorporation into the basal ice at GISP2 the results from Byrd Station are briefly reviewed.

Penetration of the ice/rock interface at Byrd Station was accompanied by upwelling of water into the drillhole, clear evidence that the basal ice was at its pressure- melting point $\left(-1.8^{\circ} \mathrm{C}\right)$. The first occurrence of lithic debris was observed $4.83 \mathrm{~m}$ above the ice/rock interface. Strongly stratified throughout, this basal debris was composed predominantly of clay-, sand- and pebblesized particles interspersed with cobbles that included large rock fragments only partially contained within the $10 \mathrm{~cm}$ diameter dimensions of the core. Most pebbles were actually sedimentary aggregates consisting of ice-cemented clay and sand that disintegrated upon melting. Up to $1 \mathrm{~cm}$ in diameter, these pebble-like clots occurred either concentrated in layers several centimeters thick or as discrete particles dispersed within the ice. These clots are believed to have originated during freezing of slurries or muddy waters formed at the base of the ice sheet. Light mineral compositions of a number of clots included quartz, plagioclase feldspars, muscovite, chlorite and kaolinite. Specific kinds of rock identified in the basal ice at Byrd Station included granite, quartz monzonite, basaltic tuff and arkosic arenite. A section of core displaying sedimentary stratification at the top of the debris zone is shown in Figure 1. The layering appears significantly inclined due to the $14-15^{\circ}$ inclination of the hole during drilling. However, the true disposition of the layers is horizontal. Ice-debris contents obtained on several pieces of core, $15-22 \mathrm{~cm}$ long, yielded debris weight percentages of $12-15 \%$.

Gas-content measurements at several different levels in the basal debris-rich ice yielded gas volumes of less than $0.2 \mathrm{ml}$ per $100 \mathrm{~g}$ of ice, compared to $10.5-12.5 \mathrm{ml}$ per $100 \mathrm{~g}$ measured in glacial ice from above the debris zone. This, and the fact that the transition from air-rich glacial ice to ice virtually devoid of air coincided with the first 
$4.83 \mathrm{~m}$

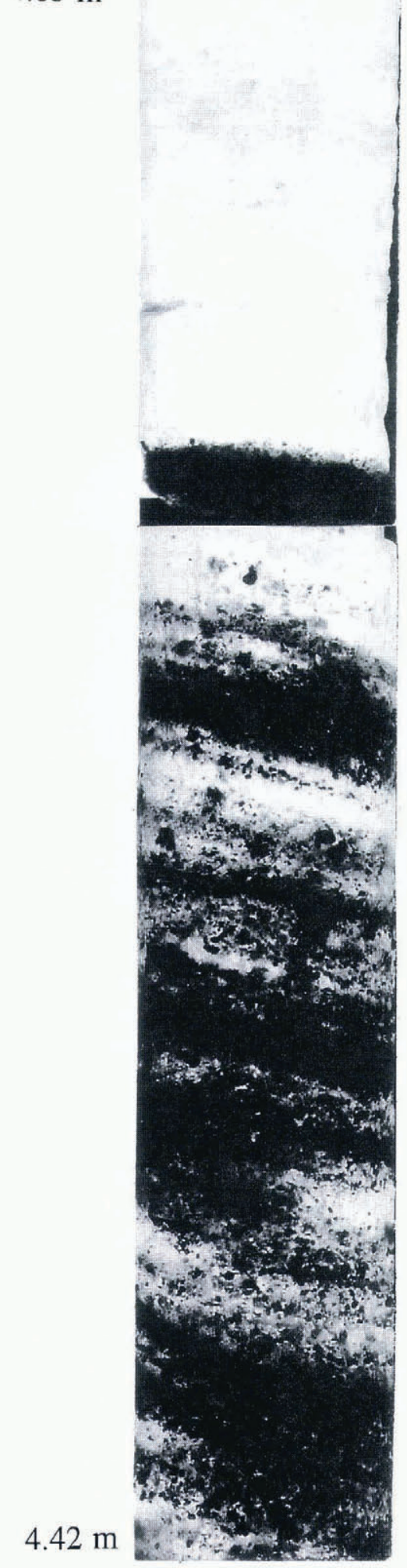

Fig. 1. Top of stratified-debris zone in basal ice of the Antarctic ice sheet at Byrd Station (after Gow and others, 1979), beginning at $4.83 \mathrm{~m}$ above the bed. Although inclined drilling makes layers appear to be inclined $\left(14^{\circ}\right)$, the true disposition of ice-debris layers is horizontal.

appearance of stratified debris, is consistent with the notion that the basal debris zone at Byrd Station originated by freezing of glacially derived meltwater, with freezing occurring slowly enough to allow rejection of virtually all air dissolved in the water. Lorius and others (1968) have also attributed the air-free nature of basal ice in East Antarctica to freezing-on of ice at the glacier bed.

Results of stable-isotope analysis of the basal debrisrich ice at Byrd Station also confirm the concept of basal freezing of meltwater and concomitant incorporation of debris. The observed $3 \%$ enrichment in the $\delta^{18} \mathrm{O}$ content of the basal ice with respect to that of actual basal meltwater agrees very closely with the magnitude and direction of change reported by O'Neil (1968) for oxygenisotope fractionation between ice and fresh water. Results of this examination of debris-rich basal ice at Byrd Station represented the first significant piece of evidence in support of the Weertman (1961) thesis that "freeze-on" of debris is a viable mechanism of basal moraine formation beneath ice sheets.

No evidence was obtained at Byrd Station to indicate that debris was incorporated into the basal ice purely by mechanical means, e.g. shearing. However, "shearing-in" of debris from the bed could be important for basal ice at sub-freezing temperatures such as that reported by Tison and others (1993) to be occurring along the margin of the Antarctic ice sheet in Terre Adélie.

Although drilling at Byrd Station was extended to a depth of $1.3 \mathrm{~m}$ into the bed, all attempts to retrieve a subglacial core were unsuccessful. This failure to extract a core would indicate that the sub-ice material consists of unconsolidated sediments, probably till or gravel. This situation would be consistent with the nature of the debris in the basal ice at Byrd Station. The demonstrated presence of substantial meltwater at the bed indicates that melting is ongoing, a situation favorable for sliding but not conducive to active erosion of the bed.

\section{GISP2 Summit site}

The situation at the GISP2 Summit site, central Greenland, differs appreciably from that at Byrd Station. At Summit a sharp transition from clear glacial to brown silty ice occurs at $3040.34 \mathrm{~m}$ depth, approximately $13.1 \mathrm{~m}$ above the ice/rock interface. Currently the basal ice at Summit is frozen to its bed at $-9^{\circ} \mathrm{C}$, approximately $6^{\circ} \mathrm{C}$ colder than the pressure-melting point. The sharpness of the glacial-ice/silty-ice transition (Fig. 2) is similar to that at Byrd Station except that occasional rock particles, up to $5 \mathrm{~mm}$ in cross-section, were observed for a distance of $15 \mathrm{~m}$ above the glacial-ice/silty-ice transition at GISP2. The top $3 \mathrm{~m}$ or so of layers of silty ice were intermixed with clear-ice layers ranging in thickness from a few millimeters to more than $10 \mathrm{~cm}$. Clear-ice layers are substantially confined to this part of the silty-ice zone (Fig. 3). Only a few thin ice layers were observed in the deeper parts of the basal ice at GISP2. Entrained debris consisted predominantly of fine-grained amber-to-browncolored sediment, mainly silt, with some sand and occasional lithic particles up to $2 \mathrm{~cm}$ in diameter. Numerous rounded particles, ranging in size from 1 to $10 \mathrm{~mm}$, were found to disintegrate on melting. These particles appear similar to the ice-cemented mud/sand clots observed in the Byrd Station basal ice cores. Preliminary measurements of particle mineralogy and chemistry indicate low-grade metamorphic and granitic terrains as source materials of the GISP2 silty ice 


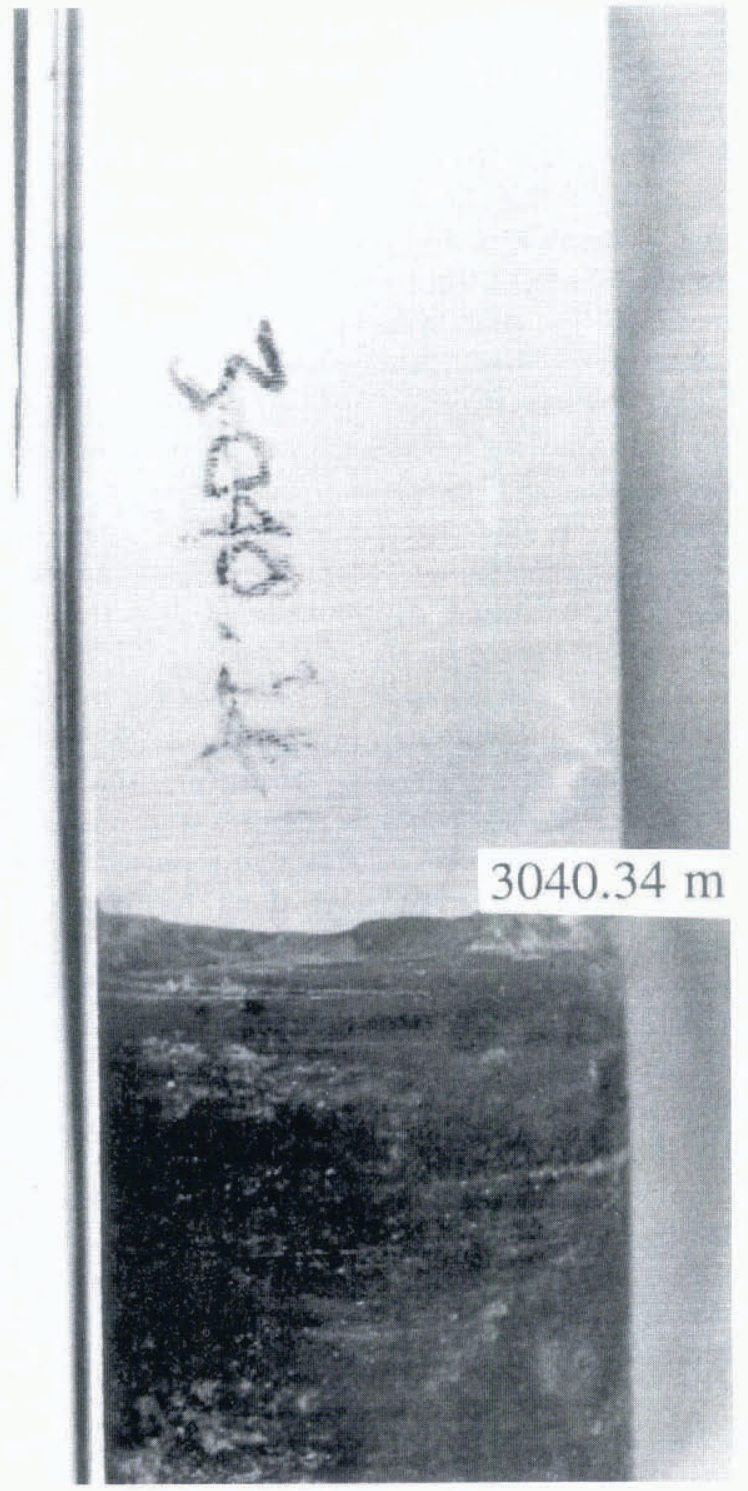

Fig. 2. Glacial-ice/silty-ice contact al $3040.34 \mathrm{~m}$ depth, located $13.1 \mathrm{~m}$ above bedrock at the GISP2 Summit site. Core diameter measures $13.2 \mathrm{~cm}$.

(personal communication from R. Souchez and J.J. Fitzpatrick).

A vertical thick section of the top $43 \mathrm{~cm}$ of brown silty ice at GISP2 (Fig. 4) reveals a number of interesting features. The contact with the glacial ice at $3040.34 \mathrm{~m}$ is indicated by the top arrow. Most of the entrained sediment is very fine-grained, but numerous rounded particles, mainly mud clots, are also dispersed throughout the ice. Clear-ice layers appear white. Their characteristic lens-like, interfingered, generally wavy appearance resembles the demonstrably deformed structures observed in glacial ice for several hundreds of meters above the bed at GISP2. This might indicate that the silty ice at GISP2 has been subject to deformation since its incorporation into the base of the ice sheet. None of the coarser-grained debris, such as cobbles and boulders, characterizing the Byrd Station basal ice was observed in the silty ice at Summit. These differences in the physical characteristics of the entrained debris at these two polar locations, in conjunction with the significantly contrasted thermal

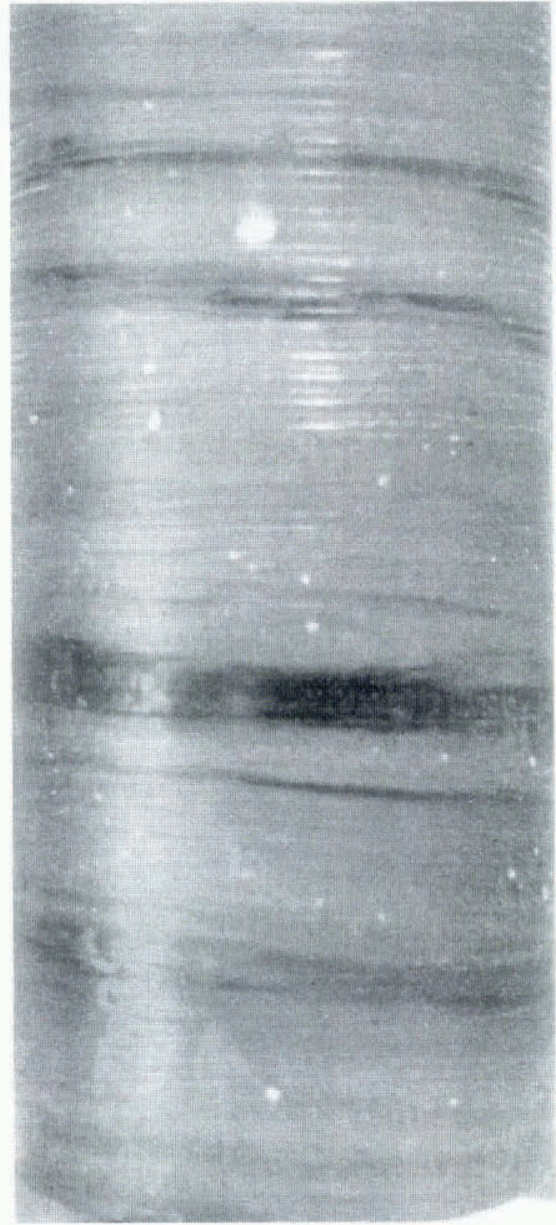

Fig. 3. Section of basal ice core from near $3043 \mathrm{~m}$ depth at GISP2, showing layers of clean ice (dark bands) interspersed with silt-rich ice containing lithic particles and mud clots (white). Core diameter measures $13.2 \mathrm{~cm}$.

states of their basal ice, indicate significantly different incorporation mechanisms for the silty ice at Summit versus the freeze-on mechanism demonstrated for Byrd Station.

Significant differences also exist in the crystallographic properties of the silty-and clear-ice layers within the basal debris zone at Summit, as amply demonstrated in Figure 5. The coarse-grained texture of the clear, sediment-free ice contrasts strikingly with the fine-grained nature of the silt-bearing ice. Additionally, the coarse-grained clear ice exhibits a multi-maximum orientation of its crystallographic $c$ axes as opposed to the strong vertical clustering of $c$ axes exhibited by the silty ice. The clearice textures and fabric are essentially identical to those observed in glacial ice directly above the silty-ice zone at GISP2. Since the glacial ice textures and fabrics bear the imprint of annealing recrystallization at elevated temperatures, it would appear that this same annealing process has also extended into the clear ice of the basal debris-laden zone. The strong single-pole fabric of the siltrich ice indicates the existence of significant shear deformation in the basal ice at GISP2

Thick-section photographs of sediment distribution in three separate silty-ice samples and their corresponding gas contents and debris concentrations are presented in Figure 6. Data from all eight silty-ice samples examined 

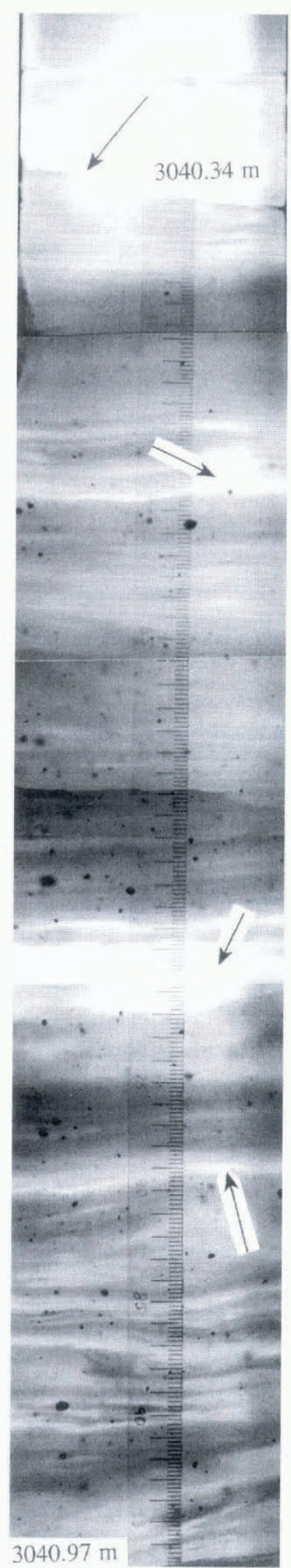

Fig. 4. Vertical thick-section photograph of the $10 p 43 \mathrm{~cm}$ of basal silty ice from GISP2. Arrow at top indicales actual glacial-ice/silty-ice transition. Additional arrows point to locations of clear silt-free ice layers. See text for a more complete description of this section of core.

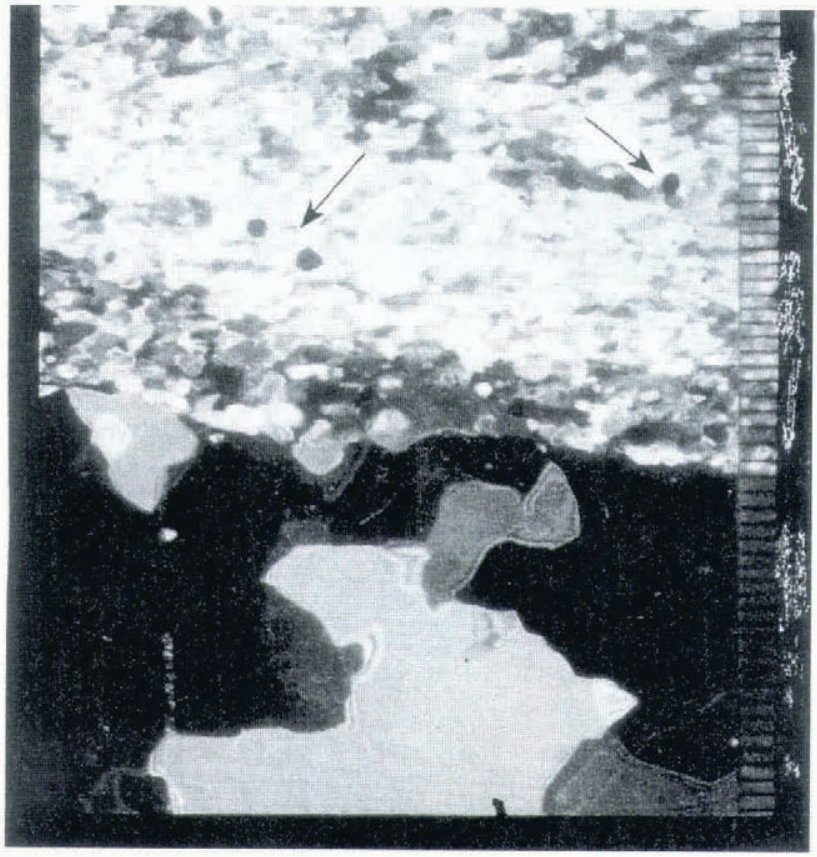

Fig. 5. Vertical thin section, photographed between crossed polarizers, showing very sharp transition between coarsegrained clean ice and fine-grained silty ice in a basal ice core from GISP2. Section measures $7.6 \mathrm{~cm}$ long and is located approximately $1 \mathrm{~m}$ into the silty-ice zone. Arrows in the silly-ice layer point to locations of mud clots.

thus far, together with gas-content measurements of four glacial ice samples $0.05,1.34,19.34$ and $39.34 \mathrm{~m}$ above the top of the silty-ice zone, are given in Table 1. Total gas contents were measured using the technique described by Langway (1958). This technique involves the collecting of gas evolved from the melting, under kerosene, of accurately weighed samples of ice. A correction was applied for gas dissolved in the meltwater, and the maximum error in the final values of total gas content is estimated at less than $7 \%$. The same siltyice samples used for gas-content measurements were also used to measure debris concentrations. This was done by simply comparing weights of oven-dried sediment with the weight of each ice sample.

Sediment loads in GISP2 basal ice range from $0.30 \%$ to $0.65 \%$ by weight. Remarkably, these data, obtained on samples $5 \mathrm{~cm}$ long, are essentially identical to debris contents calculated on the basis of density measurements made on nine separate meter-long cores of basal ice $(0.33-0.65 \%)$. Sediment loads in the GISP2 basal ice are one to two orders of magnitude less than those measured on Byrd Station basal ice cores. This in large part reflects the textural differences in rock type encountered in the basal ice at these two locations.

GISP2 silty ice contains significant amounts of entrapped gas, though somewhat less than is found in the overlying glacial ice (see Table 1). Repeat measurements on the $3053 \mathrm{~m}$ sample, from within $40 \mathrm{~cm}$ of the ice/ rock interface, and from the bottom $2 \mathrm{~cm}$ of the silty ice both revealed significant decreases in the volume of entrapped gas at the base of the silty-ice section. By contrast, the basal debris-rich ice at Byrd Station was substantially devoid of entrapped gas, an additional 


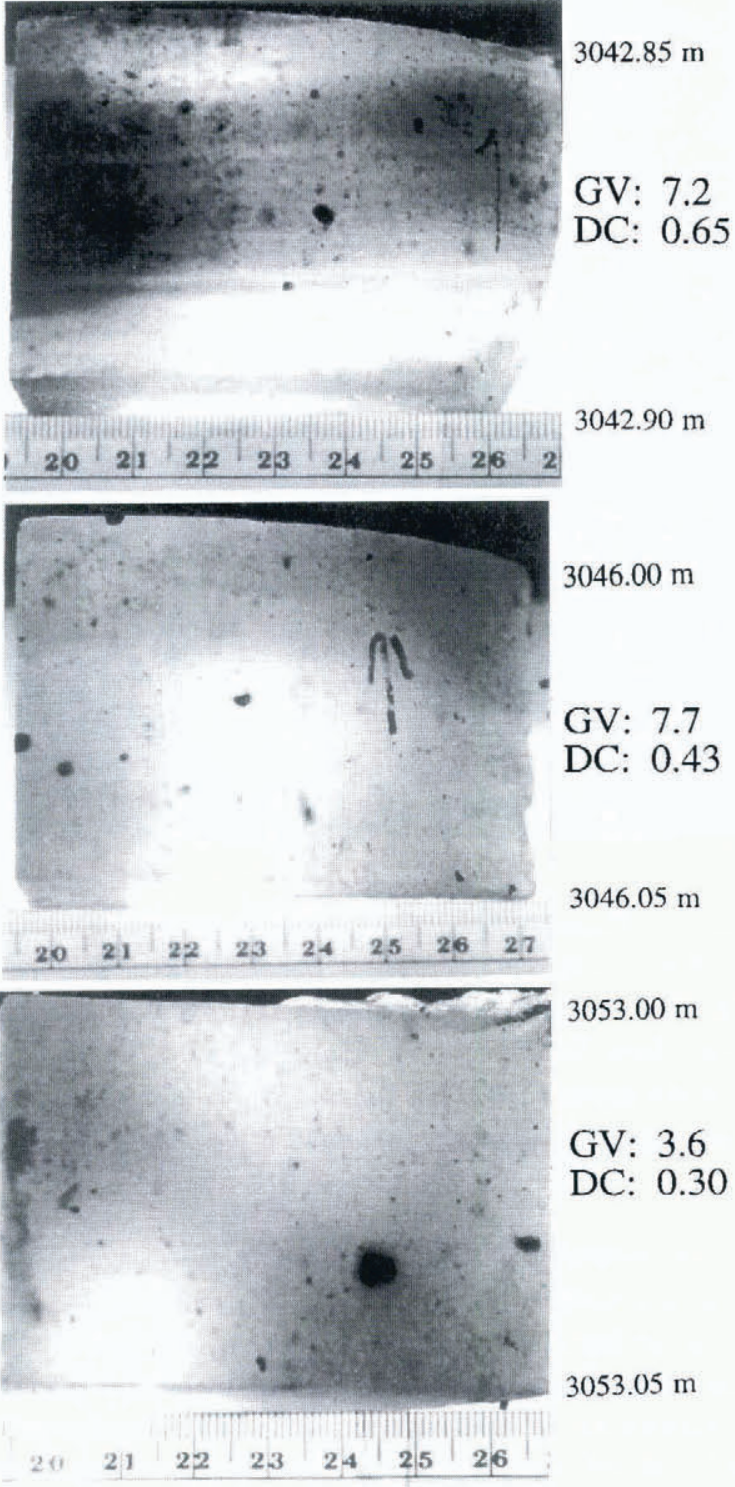

Fig. 6. Layer structure and entrained-debris characteristics of silty ice at GISP2. Larger objects in the ice include mud clots and lithic fragments. Corresponding gas volumes ( $G V$ in $\mathrm{ml}$ per $100 \mathrm{~g}$ ice) and debris concentrations (DC in \% by weight) are also given.

indicator that the debris-entrainment mechanisms at the two locations are significantly different.

The ice/rock interface at GISP2 was encountered at $3053.44 \mathrm{~m}$. This depth is the inclined depth due to the offvertical nature of the drilling. The true vertical depth, corrected for inclination, is $3047.9 \mathrm{~m}$ (personal communication from G. Clow). After several attempts to continue drilling with the ice-coring drill had proved fruitless it was decided to activate a specially designed rock-coring drill. This drill, which takes a $3.4 \mathrm{~cm}$ diameter core, penetrated $1.55 \mathrm{~m}$ of bedrock material before drilling was terminated.

It appeared from a cursory examination of the rock core at the drill site that the ice sheet at GISP2 rested on solid bedrock. However, re-examination of the core by Dr Z. Peterman of the U.S. Geological Survey, at the National Ice Core Laboratory, Denver, Colorado, showed that the top $48 \mathrm{~cm}$ consisted of surficial debris overlying the true bedrock. Dr Peterman identified
Table 1. GISP2 basal ice samples

\begin{tabular}{ccc}
\hline $\begin{array}{c}\text { Depth range of } \\
\text { entrained sediment }\end{array}$ & $\begin{array}{c}\text { Debris } \\
\text { concentration } \\
\text { meight } \%\end{array}$ & $\begin{array}{c}\text { Gas content } \\
\text { ml per 100 g } \\
\text { (STP) }\end{array}$ \\
\hline $3001.00-.03$ & - & 9.6 \\
$3021.00-.03$ & - & 9.8 \\
$3039.00-.03$ & - & 9.3 \\
$3040.29-.31$ & - & 9.0 \\
$3040.38-.40$ & n.d. & 7.7 \\
$3042.85-.90$ & 0.65 & 7.2 \\
$3044.00-.05$ & 0.24 & 8.0 \\
$3046.00-.05$ & 0.43 & 7.7 \\
$3048.00-.05$ & 0.35 & 7.5 \\
$3051.06-.11$ & 0.38 & 7.6 \\
$3053.00-.05$ & 0.30 & 3.6 \\
$3053.42-.44$ & n.d. & 3.0 \\
& & \\
\hline
\end{tabular}

schistose rock in the top $20 \mathrm{~cm}$ followed by fresh biotite granite to $35 \mathrm{~cm}$. Between 35 and $39 \mathrm{~cm}$ a vertical contact separated granite from a "dioritic-looking" rock. This in turn was underlain by $10 \mathrm{~cm}$ of unconsolidated now frozen) material, possibly soil, consisting of silt and coarse clasts $(1-2 \mathrm{~cm})$ of both granitic and mafic rock. The true bedrock consisted of gray, medium-grained biotite granite. This entire subglacial core is now being studied for a variety of petrographic, petrochemical and traceelement properties, including cosmogenic radionuclide studies to determine the exposure age of the rock in contact with the basal ice. A photograph of the top $63 \mathrm{~cm}$ of rock core is shown in Figure 7.

\section{Comparisons with GRIP}

A parallel drilling project was conducted by the Greenland Ice Core Project (GRIP) on the crest of the Greenland ice sheet, located about $30 \mathrm{~km}$ upstream of the GISP2 drilling site. At GRIP, silty ice similar in nature to that at GISP2, was encountered at a depth of $3022.5 \mathrm{~m}$. After drilling a little more than $6 \mathrm{~m}$ of silty ice, mechanical problems with the drill caused premature termination of coring. Since the distance to the bed is not accurately known, the actual thickness of the silty-ice layer at GRIP is also not known. Nevertheless, GRIP researchers have carried out very comprehensive analyses of the $6 \mathrm{~m}$ of silty ice they obtained. Results dealing with petrographic, ice-structure, stable-isotope and gas analyses have been reported in a series of excellent papers, including Souchez and others (1994), Tison and others (1994) and Souchez and others (1995a, b).

According to Tison and others (1994), the basal ice at GRIP includes a number of regions, up to $50 \mathrm{~cm}$ thick, that contain less than $0.06 \%$ by weight of debris. Peak values near the bottom of the $6 \mathrm{~m}$ long silty-ice core reached $0.30 \%$ by weight of sediment. These sediment loads are appreciably lower than at GISP2, where values range from $0.24 \%$ to $0.65 \%$. This is true of samples 


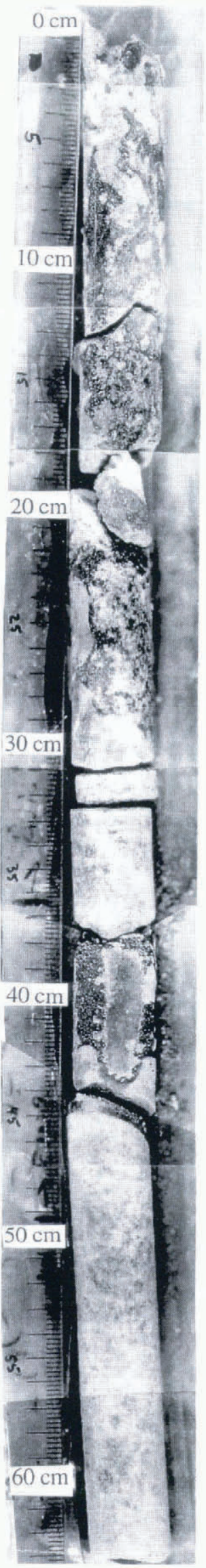

Fig. 7. Core from the lop $63 \mathrm{~cm}$ of "bedrock" underlying the Greenland ice sheet at the GISP2 Summil site. This rock core, $3.4 \mathrm{~cm}$ in diameter, fealures what appear to be cobbles and/or boulders in the top $38 \mathrm{~cm}$, overlying or embedded in unconsolidated (now frozen) breccia or soil, possibly till. A sharp transition to gray granitic bedrock occurs at $46-48 \mathrm{~cm}$. See lext for more complete details. ranging in size from a few centimeters to as much as $1 \mathrm{~m}$ in length. Based on values measured at GISP2 compared to results given by Tison and others (1994), it would appear that the sediment load in basal ice at GISP2 is about three to four times greater than at GRIP.

Total gas content in silty ice both at GISP2 and at GRIP appear similar, averaging around $7 \mathrm{ml}$ per $100 \mathrm{~g}$ of ice. However, measurements on silty ice located just above the bed at GISP2 showed a significant decrease in gas content to about $3.0 \mathrm{ml}$ per $100 \mathrm{~g}$ of ice.

According to Souchez and others (1995a), $\mathrm{CO}_{2}$ and $\mathrm{CH}_{4}$ concentrations in basal silty ice at GRIP are so high (up to 130000 ppmv for $\mathrm{CO}_{2}$ and $6000 \mathrm{ppmv}$ for $\mathrm{CH}_{4}$ ) as to preclude a direct atmospheric origin for these gases. A strong connection with organic sources is indicated. Taken in conjunction with stable-isotope analyses and studies of the textures and fabrics of the basal ice, the gas data provide supporting evidence for the view expressed by the GRIP researchers that the basal silty ice at Summit originated locally as ground-ice, possibly in a marshy environment. Only after build-up of the main ice sheet was this ground-ice subsequently overridden and incorporated into the base (Souchez and others, 1994; Tison and others, 1994).

Data obtained so far at GISP2 is not incompatible with the ground-ice origin postulated for the basal ice at GRIP. Final determination of the situation at GISP2 must await results of gas-composition and stable-isotope studies under way at this time. The contact between glacial ice and the underlying silty ice would seem, notwithstanding, to represent a major discontinuity. Souchez and others (1994) suggest that the basal ice at Summit could represent the original build-up phase of the Greenland ice sheet, extending as far back as $2.4 \times 10^{6}$ years ago. However, determining the precise timing of ice-sheet build-up and the subsequent override of the basal ice will be difficult, though the possibility of determining, by cosmogenic radionuclides, the exposure age of the rock in contact with the basal ice may provide a clue.

The soil- or till-like nature of the surficial debris overlying the true bedrock at GISP2 contrasts significantly with the fine-grained textural characteristics of the silty ice overlying it, indicating little if any direct relationship between the two. This observation further reinforces the notion that the silty ice did not originate by direct interaction of the ice sheet with the bed.

There is no evidence that debris in the basal ice at GISP2 was incorporated recently. The current bed temperature of $-9^{\circ} \mathrm{C}$ at GRIP precludes sliding, making it very unlikely that active erosion is occurring at this location beneath the Greenland ice sheet.

Apart from GISP2, the only other complete penetration of the Greenland ice sheet was at Camp Century where $15.7 \mathrm{~m}$ of debris-laden ice was encountered prior to entering bedrock composed of frozen till-like material (Herron and Langway, 1979). Appreciable entrapped gas observed in the upper layers of the basal ice was attributed to downward diffusion of air from the overlying glacial ice into originally bubble-free, debrisrich ice, which Herron and Langway (1979) concluded originated by a freeze-on process similar to that demonstrated at Byrd Station. 


\section{CONGLUSIONS}

Basal ice properties, thermal conditions at the ice/rock interface and bedrock composition have been investigated in cores from drillholes in Antarctica and Greenland that penetrated the bottoms of both ice sheets. Cores from the bottom $4.83 \mathrm{~m}$ of the Antarctic ice sheet at Byrd Station contained abundant stratified debris ranging from silt-sized particles to cobbles. The nature and disposition of the debris, together with measurements of the physical properties of the enclosing ice, including stable-isotope and entrapped-gas analyses, are consistent only with a process of "freeze-on" of meltwater at the ice/rock interface. The underlying bedrock material is unconsolidated, probably watersaturated gravel or till. The first appearance of debris at $4.83 \mathrm{~m}$ above the bed coincided with the virtual loss of all air from the ice. This transition represents a major discontinuity, separating snow-derived glacial ice from above and basally accreted ice from below. It is likely that the formation of debris-laden ice at Byrd Station was an episodic process in which freezing-on of debris alternated with basal melting. Significant upwelling of water following penetration of the ice/rock interface would indicate that basal melting rather then accretion was occurring at that time.

A significantly different situation appears to prevail at GISP2, Summit, central Greenland, where the $13.1 \mathrm{~m}$ of silty basal ice lacks the coarser-grained particles present in basal ice at Byrd Station. Studies of the nature and disposition of the entrained debris at GISP2, together with measurements of the total gas content of the ice and its sediment load, support the results from the adjacent GRIP core indicating that the basal silty ice at Summit originated as ground-ice prior to the growth of the current ice sheet. It is conjectured that the ice sheet subsequently overrode the silt-bearing ground-ice and incorporated it into its base. This explanation implies that the formation of the silty ice at Summit occurred independently of the present-day ice sheet without any direct interaction with the underlying bedrock such as applies to basal ice formation at Byrd Station. Bedrock material at GISP2 consists of boulders and residual soil for a distance of $48 \mathrm{~cm}$ beneath the ice/rock interface, underlain by true bedrock composed of gray granite. Cosmogenic radionuclide analyses, providing exposure ages of bedrock core in immediate contact with basal ice at GISP2, may help to determine the most recent date of glaciation of the Summit region of Greenland. Despite their contrasted basal thermal regimes, wet at Byrd Station and frozen at GISP2, there is no compelling evidence of significant erosion occurring at the bed at either location.

\section{ACKNOWLEDGEMENTS}

This work was funded by the Office of Polar Programs of the U.S. National Science Foundation. This support, and that of the 109th Squadron of the New York Air National Guard and the Polar Ice Coring Office of the University of Alaska, Fairbanks for logistical and drilling assistance in Greenland, is gratefully acknowledged. We are indebted to our many colleagues who participated with us in the Greenland Ice Sheet Project and to our CRREL co-workers who assisted us in the preparation of the manuscript.

\section{REFERENCES}

Gow, A.J., S. Epstein and W. Sheehy. 1979. On the origin of stratified debris in ice cores from the bottom of the Antarctic ice sheet. $J$. Glaciol., 23 89), 185-192.

Herron. S. and C. C. Langway, Jr. 1979. The debris-laden ice at the bottom of the Greenland ice sheet. J. Glaciol., 23 89), 193-207.

Langway, C. C., Jr. 1958. Bubble pressures in Greenland glacier ice. International Association of Scientific Hydrology Publication 47 (Symposium at Chamonix 1958-Physics of the Movement of the Ice), 336-349.

Lorius, C., D. Raynaud and L. Dolle. 1968. Densité de la glace et étude des gaz en profondeur dans un glacier antarctique. Tellus, 203 , 449459 .

O'Neil, J. R. 1968. Hydrogen and oxygen isotope fractionation between ice and water. J. Phys. Chem., 72 (10), 3683-3684.

Souchez, R. and 8 others. 1994. Stable isotopes in the basal silty ice preserved in the Greenland ice sheet at Summit: environmental implications. Geophys. Res. Lett., 21 8), $693-696$.

Souchez, R., M. Lemmens and J. Chappellaz. 1995a. Flow-induced mixing in the GRIP basal ice deduced from the $\mathrm{CO}_{2}$ and $\mathrm{CH}_{4}$ records. Geophys. Res. Letl., 22 (1), 41-44.

Souchez, R., L. Janssens, M. Lemmens and B. Stauffer. 1995b. Very low oxygen concentration in basal ice from Summit, central Greenland. Geophys. Res. Lell., 22 (15), $2001-2004$.

Tison, J.-L.. J.-R. Petit, J. -M. Barnola and W. C. Mahaney. 1993. Debris entrainment at the ice-bedrock interface in sub-fieezing temperature conditions (Terre Adélie, Antarctica). J. Gilaciol., $39132), 303-315$.

Tison, J. -L., T. Thorsteinsson, R. D. Lorrain and J. Kipfstuhl. 1994. Origin and development of textures and fabrics in basal ice at Summit, central Greenland. Earth Planet. Sci. Letl., 125, 421-437.

Weertman, J. 1961. Mechanism for the formation of inner moraines found near the edge of cold ice caps and ice sheets. \%. Glaciol., 3 (30), 965978. 